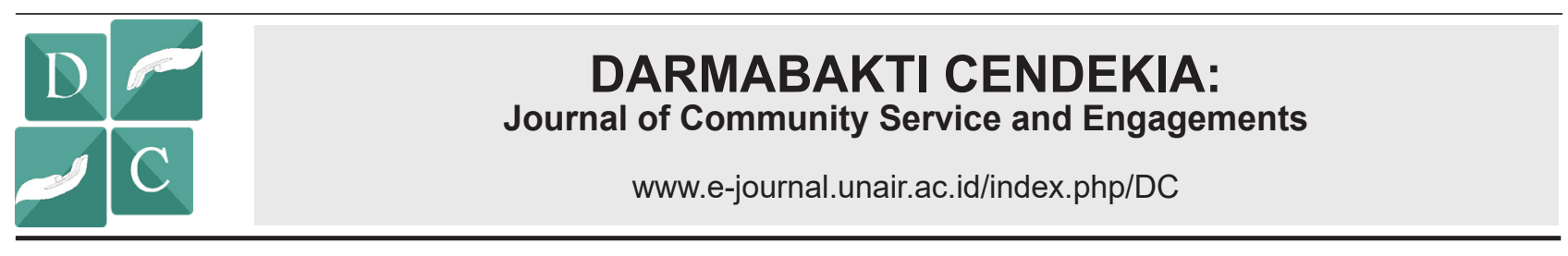

\section{TRAINING OF KAHOOT! AS AN INTERACTIVE GAME-BASED LEARNING EVALUATION PLATFORM FOR STUDENTS}

\author{
PELATIHAN KAHOOT! SEBAGAI PLATFORM EVALUASI \\ PEMBELAJARAN BERBASIS GAME YANG INTERAKTIF UNTUK \\ SISWA
}

Scope:

Applied Science

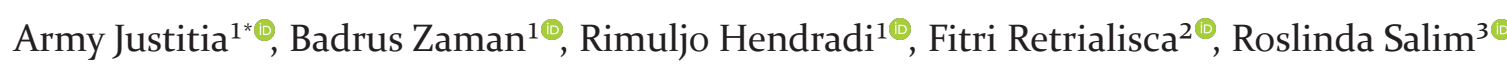

${ }^{1}$ Bachelor of Information Systems Study Program, Faculty of Science and Technology, Universitas Airlangga, Surabaya-Indonesia ${ }^{2}$ Diploma-III of Information Systems Study Program, Faculty of Vocational Studies, Universitas Airlangga, Surabaya-Indonesia ${ }^{3}$ Department of Media Science and Graphic, Faculty of Information Sciences and Engineering, Management and Science University, Shah Alam-Malaysia
\end{abstract}

\begin{abstract}
A $B S T R A C T$
Background: Maintaining student motivation, involvement and consistency in a learning process is a challenge that must be faced by teachers / educators. Especially during the COVID-19 pandemic, this limits learning activities in online form. Teachers / educators need additional skills to be able to manage classes, deliver material and maintain student motivation. Objective: This community service aims to improve the skills of teachers / educators to provide interactive learning and evaluation media based on game learning. Methods: The methods used in this community service activity were training and focus group discussions. Furthermore, the participants prepared the Kahoot quiz material independently according to the subjects they were teaching them. Result: The result of this training activity is an increase in the skills of teachers / educators in mastering Kahoot, and an increase in teacher / educator understanding of the Kahoot material. This can be seen from the occasional increase of $15.97 \%$ after the training was completed. The training participants were satisfied with the implementation of the training as evidenced by filling out the feedback questionnaire, with a satisfaction score above 3.5 out of 4 . Conclusion: This community service has a positive impact on skills and understanding related to the use of Kahoot for interactive learning and evaluation media.
\end{abstract}

\section{A B S T R A K}

Latar belakang: Menjaga motivasi, keterlibatan dan konsistensi siswa dalam sebuah proses pembelajaran merupakan tantangan tersendiri yang harus dihadapi oleh guru/ pendidik. Terutama di masa pandemi COVID-19 yang membatasi kegiatan pembelajaran dalam bentuk daring. Guru/pendidik memerlukan keterampilan tambahan agar mampu mengelola kelas, menyampaikan materi dan menjaga motivasi siswa. Tujuan: Kegiatan pengabdian kepada masyarakat ini bertujuan untuk meningkatkan ketrampilan guru/ pendidik untuk memberikan media pembelajaran dan evaluasi yang interaktif berbasis pembelajaran game. Metode: Metode yang digunakan dalam kegiatan pengabdian kepada masyarakat ini adalah dengan pelatihan dan focus group discussion. Selanjutnya peserta menyiapkan materi quis Kahoot secara mandiri sesuai dengan mata pelajaran yang diampu masing-masing. Hasil: Hasil dari kegiatan pelatihan ini adalah meningkatnya ketrampilan guru/pendidik dalam menguasai Kahoot, dan meningkatnya pemahaman guru/pendidik terhadap materi Kahoot. Hal ini terlihat dari adanya peningkatan sebanyak $15.97 \%$ setelah pelatihan selesai. Peserta pelatihan merasa puas dengan pelaksanaan pelatihan yang dibuktikan dengan pengisian kuesioner feedback, dengan nilai kepuasan di atas 3,5 dari 4. Kesimpulan: Kegiatan pengabdian kepada masyarakat ini memberikan dampak positif terhadap keterampilan dan pemahaman terkait penggunaan Kahoot untuk media pembelajaran dan evaluasi yang interaktif.

\author{
ARTICLE INFO \\ Received 17 November 2020 \\ Revised 23 April 2020 \\ Accepted 16 April 2021 \\ Online 28 June 2021 \\ *Correspondence (Korespondensi): \\ Army Justitia \\ E-mail: \\ army-j@fst.unair.ac.id
}

Keywords:

Evaluation learning, Focus group discussion, Interactive, Game-based learning, Training

Kata kunci:

Evaluasi Pembelajaran, Focus Group Discussion, Interaktif, Pembelajaran berbasis game, Pelatihan 


\section{PENDAHULUAN}

Pesatnya perkembangan teknologi informasi juga telah memberikan dampak ke dunia pendidikan. Pengembang-pengembang aplikasi telah menyadari kendala-kendala yang muncul di dunia pendidikan, terutama permasalahan evaluasi pembelajaran konvensional (Arisandi et al., 2018; Heriadi \& Satyareni, 2013). Beberapa apllkast dan platform telah banyak dluncurkan untuk membantu para guru/pendidik dalam menyampaikan materi pelajaran agar lebih mudah diterima oleh siswa. Ada beberapa platform pembelajaran online (disebut juga learning management system - LMS) populer dan free digunakan oleh sekolah, lembaga pendidikan, atau universitas, antara lain Moddle (Costa et al, 2012; Oproiu, 2015) dan Edmodd (Cao \& Liu, 2019; Fauzi, 2017). Kedua platform ini menawarkan titur yang lengkap dan handal untuk pembelajaran online (Retnoningsih, 2017). Namun sayangnya, platform tersebut sering kali dikeluhkan pengguna, karena tidak user friendly dan tidak ease of use.

Seiring dengan berkembangnya teknologi informasi, memunculkan banyaknya aplikasi pembelajaran yang mengusung tema interaktif. Metode pembelajaran interaktif diyakini mampu meningkatkan dan mempercepat daya tangkap, dan pemahaman siswa. Salah satu komponen pada media pembelajaran interaktif adalah komponen audio dan visual (Haryoko, 2009), selain komponen text. Untuk proses evaluasi pembelajaran, aplikasi yang bertema interaktif salah satunya adalah Hot Potatoes. Hot Potatoes harus disisipkan dalam platform Moodle atau Edmodo untuk membuat soal lebih interaktif (Syamsinar et al., 2020; Yasa, 2020). Selain Hot Potatoes, aplikasi powerfull yang lainnya adalah Kahoot!. Aplikasi Kahoot! mengadaptasi konsep belajar melalui permainan (gaming). Pembelajaran berorientasi game (game-based learning) merupakan bentuk pembelajaran terbaik (best practice) (Dellos, 2015). Siswa diberikan pengalaman belajar yang santai, keterlibatan yang tinggi, meningkatkan motivasi, dan yang terpenting adalah siswa belajar tanpa menyadarinya. Kahoot! dapat digunakan untuk evaluasi pembelajaran yang berbentuk quis, pre-test, post-test, bahkan untuk keperluan ice breaking.

Media pembelajaran dan evaluasi interaktif mutlak diperlukan untuk mengembalikan dan menjaga motivasi, keterlibatan dan konsentrasi siswa dalam proses pembelajaran. Apalagi di masa era normal akibat pandemi COVID-19 yang memaksa peserta didik untuk belajar dari rumah atau belajar jarak jauh. Kemampuan mengelola kelas, menyampaikan materi, dan menjaga motivasi siswa didik diperlukan media, sarana dan keterampilan tambahan. Namun sayangnya, sebagian besar tenaga pendidik Indonesia, terutama di jenjang pendidikan sekolah menengah atas dan jenjang dibawahnya lagi, masih kekurangan keterampilan dalam membuat media pembelajaran dan evaluasi yang interaktif.

Melalui kegiatan pengabdian kepada masyarakat, penulis menyelenggarakan pelatihan penggunaan game creator Kahoot! untuk media evaluasi yang interaktif. Pelatihan ini bertujuan memberikan tambahan keterampilan yang dapat membantu tugas para pendidik dalam memberikan media pembelajaran dan evaluasi yang interaktif berbasis pembelajaran games. Setelah kegiatan pengabdian kepada masyarakat ini selesai, diharapkan para pendidik mampu mengimplementasikan Kahoot! sebagai media evaluasi pembelajaran untuk meningkatkan antusiasme siswa dalam proses pembelajaran.

\section{METODE}

Kegiatan pengabdian kepada masyarat ini menggunakan metode pelatihan dan focus group discussion untuk meningkatkan kemampuan guruguru dalam penguasaan teknologi informasi di dunia pendidikan. Pada awalnya, pelatihan akan dilakukan secara langsung ke para guru-guru yang ada di kecamatan Sangkapura, Bawean. Namun, karena kondisi pandemi COVID-19, maka diputuskan pelatihan dilakukan secara daring (online). Peserta pelatihan kemudian dibuka untuk guru-guru secara umum, baik dari guru TK atau playgroup sampai dengan guru di tingkat pendidikan menengah keatas (SMA).

Pelatihan yang mengusung tema "Kahoot!: Sebuah Platform Evaluasi Pembelajaran yang Interaktif" diambil dan diputuskan dari pertimbangan bahwa selama ini proses evaluasi pembelajaran dirasa membosankan. Apalagi ditambah dengan kondisi pandemic COVID-19 yang memaksa guru maupun siswa belajar dari laptop masing-masing. Untuk melangsungkan pelatihan ini, diperlukan sebuah modul pelatihan yang membantu peserta pelatihan memahami isi pelatihan. Selain itu, peserta pelatihan sudah harus memiliki akun email di Google Mail, Yahoo, ataupun akun email lainnya. Akun email ini kemudian digunakan untuk proses pembuatan akun di Kahoot!.

Evaluasi dari kegiatan pelatihan ini menggunakan kuesioner untuk pre-test dan post-test kepada peserta. Kuesioner pre-test digunakan untuk mengetahui pengetahuan yang sudah dimiliki peserta terhadap materi pelatihan. Kuesioner post-test digunakan untuk mengetahui peningkatan pengetahuan yang 
dimiliki oleh peserta setelah dilakukan penelitian. Selain kuesioner pre-test dan post-test, peserta juga harus mengisi kuesioner feedback sebagai bentuk respon peserta terhadap kualitas materi, kualitas pemaparan instruktur dan keseluruhan penyelenggaraan pelatihan ini.

\section{HASIL DAN PEMBAHASAN}

Semenjak diputuskan bahwa pelatihan ini dilakukan secara daring dan peserta terbuka untuk umum, terutama dikhususkan untuk guruguru, maka sosialisasi pelatihan ini menggunakan media sosial (Facebook, Instagram, dan Whatsapp Group). Sebanyak 337 peserta ingin bergabung dan teregistrasi dalam pelatihan Kahoot!, dengan distribusi peserta bisa dilihat pada Tabel 1. Peserta berasal dari Indonesia sebanyak 330 peserta (97,63\%), dari Myanmar sebanyak 5 peserta $(1,48 \%)$ dan dari Malaysia sebanyak 3 peserta (0,89\%). Jika dilihat dari jenjang institusi, peserta mayoritas berasal dari jenjang SMA / MA / SMK sebanyak 128 peserta $(39,94)$, dari jenjang SMP / MTS sebanyak 112 peserta $(33,14 \%)$, dari jenjang SD / MI sebanyak 52 peserta (15,38\%), sisanya dari jenjang perguruan tinggi dan TK. Sebagian besar peserta yang ikut pada pelatihan ini adalah guru dengan sebanyak 298 peserta (88.17\%), disusul kepala sekolah sebanyak 16 peserta $(4,73 \%)$, sisanya adalah dari staff administrasi sekolah, mahasiswa, dosen, dan tenaga pendidikan lain. Maka dapat disimpulkan bahwa pelatihan ini sudah tepat sasaran, yaitu untuk stakeholder yang bergerak di bidang pendidikan.

Pelatihan ini dikemas dalam bentuk pengabdian kepada masyarakat internasional (International Community Services) secara virtual. Kegiatan ini diinisiasi oleh program studi S1 Sistem Informasi Fakultas Sains dan Teknologi yang menggandeng program studi D3 Sistem Informasi Fakultas Vokasi, Universitas Airlangga, berkolaborasi dengan Faculty of Information

Tabel 1. Distribusi Peserta Pelatihan Kahoot!
Science and Engineering (FISE), Management and Science University (MSU), Malaysia. Pelatihan Kahoot! diadakan menggunakan platform Zoom (lihat Gambar 1), dan streaming langsung ke channel YouTube dari Himpunan Mahasiswa Sistem Informasi https://www.youtube.com/watch?v=d$8 M 7 H E V$ rew (lihat Gambar 2) Peserta yang ikut pelatihan melalui Zoom sebanyak 175 peserta, sedangkan peserta yang menonton dari channel YouTube sebanyak hampir 150 peserta. Peserta terlihat antusias dengan materi Kahoot! dengan banyaknya pertanyaan-pertanyaan yang diajukan ke instruktur. Materi yang disampaikan dalam pelatihan Kahoot! ini terdiri dari 3 sesi, yaitu sesi membuat quiz di Kahoot!, sesi memainkan quiz di Kahoot! dan sesi analisis dan laporan dari quiz di Kahoot!.

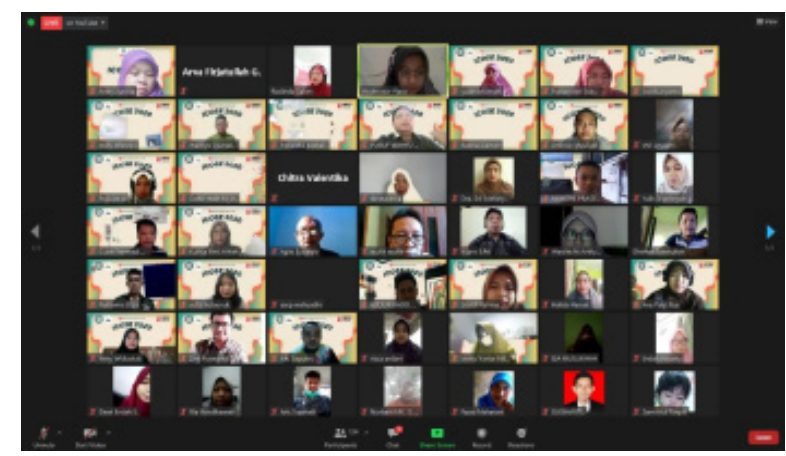

Gambar 1. Zoom Class dari kegiatan pelatihan Kahoot!

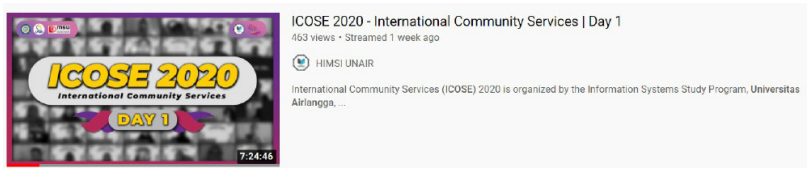

Gambar 2. Streaming YouTube kegiatan pelatihan Kahoot!

Untuk terus melakukan continuous improvement, perlu dilakukan evaluasi terhadap pelatihan, baik dari segi pelaksanaan maupun untuk isi dari materi pelatihan. Evaluasi terhadap pelaksaan kegiatan ini dilakukan dengan metode angket survey dengan skala 1-4, dimana semakin

\begin{tabular}{|c|c|c|c|c|c|}
\hline Kriteria & Jumlah & $\%$ & Kriteria & Jumlah & $\%$ \\
\hline Negara Peserta & & & Jabatan di Institusi & & \\
\hline Indonesia & 330 & 97,63 & Guru & 298 & 88,17 \\
\hline Myanmar & 5 & 1,48 & Kepala Sekolah & 16 & 4,73 \\
\hline \multirow[t]{2}{*}{ Malaysia } & 3 & 0,89 & Mahasiswa & 8 & 2,37 \\
\hline & & & Dosen & 6 & 1,78 \\
\hline Jenjang Institusi & & & Staff Administrasi & 4 & 1,18 \\
\hline TK & 6 & 1,78 & Tenaga pendidikan & 6 & 1,78 \\
\hline SD / MI & 52 & 15,38 & lain-lain (IT, Pengawas, & & \\
\hline SMP / MTs & 112 & 33,14 & Pembina Olimpiade, & & \\
\hline SMA / MA / SMK & 128 & 39,94 & Koordinator, Wakil & & \\
\hline Perguruan Tinggi & 33 & $\begin{array}{c}39,94 \\
9,76\end{array}$ & Dekan, Waka Sarana dan & & \\
\hline
\end{tabular}


tinggi nilai semakin puas peserta terhadap pelaksanaan kegiatan ini. Survei ini menggunakan fasilitas dari Google Form yang dibagikan ke peserta setelah sesi pelatihan berakhir. Peserta merasa puas dengan pelaksanaan kegiatan ini, yang ditunjukkan dengan rata-rata nilai 3,57. Peserta merasa materi yang disajikan sangat bermanfaat untuk membantu tugas guru. Hal ini ditunjukkan dari hasil evaluasi sebesar 3,73. Begitu pula terkait fasilitas yang didapatkan, peserta merasa sangat puas, misalnya kemudahan dalam

Tabel 2. Indikator Evaluasi Pelaksanaan Pelatihan Kahoot! registrasi, modul, dan e-sertifikat. Detilinformasi hasil evaluasi ini dapat dilihat pada Tabel 2.

Sebelum sesi pelatihan dimulai, peserta diminta untuk mengerjakan pre-test sebanyak 10 pertanyaan. Setelah pelatihan selesai, peserta diminta kembali untuk mengerjakan post-test dengan pertanyaan yang sama dengan pretest. Tujuan dari pre-test dan post-test ini adalah untuk mengukur tingkat keberhasilan pelatihan yang dilakukan. Indikator pemahaman materi yang disampaikan beserta peningkatan setelah pelatihan bisa dilihat pada Tabel 3 .

\begin{tabular}{clc}
\hline No. & \multicolumn{1}{c}{ Indikator } & Nilai \\
\hline 1 & Cakupan atau lingkup materi & 3,63 \\
2 & Sistematika atau urutan penyajian materi & 3,56 \\
3 & Manfaat materi dalam membantu tugas guru & 3,73 \\
4 & Kemutakhiran materi yang disampaikan & 3,62 \\
5 & Tingkat pemahaman Anda terhadap materi & 3,40 \\
6 & Kesesuian strategi pelatihan yang digunakan dengan tujuan & 3,56 \\
7 & Media yang digunakan dalam pelatihan & 3,60 \\
8 & Kesesuaian waktu yang disediakan dengan strategi pelatihan & 3,50 \\
9 & Pemilihan waktu yang disediakan dengan strategi pelatihan & 3,50 \\
10 & Pengaturan jadwal pelatihan & 3,51 \\
11 & Kesempatan peserta untuk menyampaikan gagasan & 3,55 \\
12 & Interaksi penyaji dengan peserta & 3,58 \\
13 & Kualitas pelaksanaan pelatihan secara umum & 3,55 \\
14 & Fasilitas pelatihan(registrasi, modul, e-sertifikat) & 3,68 \\
15 & Penyajian materi oleh pemateri & 3,59 \\
& Indikator & 3,57 \\
\hline
\end{tabular}

Tabel 3. Indikator Evaluasi Pemahaman Materi Pelatihan Kahoot!

\begin{tabular}{|c|c|c|c|c|c|c|}
\hline & \multirow[b]{2}{*}{ Indikator } & \multicolumn{2}{|c|}{ Pre-test } & \multicolumn{2}{|c|}{ Post-test } & \multirow{2}{*}{$\begin{array}{c}\text { Peningkatan } \\
\text { Pemahaman } \\
\text { Materi (\%) }\end{array}$} \\
\hline & & $\begin{array}{c}\text { Tahu / } \\
\text { Paham } \\
(\%)\end{array}$ & $\begin{array}{c}\text { Tidak Tahu / } \\
\text { Tidak Paham } \\
\text { (\%) }\end{array}$ & $\begin{array}{c}\text { Tahu / } \\
\text { Paham } \\
(\%)\end{array}$ & $\begin{array}{c}\text { Tidak Tahu / } \\
\text { Tidak Paham } \\
\text { (\%) }\end{array}$ & \\
\hline 1 & Akses Kahoot! untuk dimainkan peserta & 39,83 & 60,17 & 70,65 & 29,35 & 30,82 \\
\hline 2 & Akses Kahoot! untuk membuat quiz & 61,44 & 38,56 & 67,75 & 32,25 & 6,31 \\
\hline 3 & Fitur-fitur pada Kahoot! & 48,31 & 51,69 & 70,29 & 29,71 & 21,98 \\
\hline 4 & Fitur pada report dan analytic Kahoot! & 26,69 & 73,31 & 38,04 & 61,96 & 11,35 \\
\hline 5 & Keunggulan Kahoot! & 43,63 & 56,36 & 58,33 & 41,67 & 14,69 \\
\hline 6 & Cara akses Kahoot! & 35,59 & 64,41 & 48,19 & 51,81 & 12,60 \\
\hline 7 & Pilihan jawaban pada Kahoot! & 38,14 & 61,86 & 63,41 & 36,59 & 25,27 \\
\hline 8 & Akses Kahoot! melalui email & 91,10 & 8,90 & 92,75 & 7,25 & 1,65 \\
\hline 9 & Pemberian score pada Kahoot! & 19,49 & 80,51 & 46,38 & 53,62 & 26,89 \\
\hline 10 & Kolaborasi dengan akun lain & 84,32 & 15,68 & 89,49 & 10,51 & 5,17 \\
\hline 11 & Akses bermain dengan akun lain & 81,36 & 18,64 & 92,03 & 7,97 & 10,67 \\
\hline \multirow[t]{2}{*}{12} & Setting jumlah pilihan pada Kahoot! & 49,15 & 50,85 & 72,83 & 27,17 & 23,67 \\
\hline & Rata-rata & 51,59 & 48,41 & 67,51 & 32,48 & 15,92 \\
\hline
\end{tabular}


Secara umum, kemampuan peserta terjadi peningkatan di setiap indikator. Hal ini terlihat dari meningkatnya hasil rerata dari post-tes, dibandingkan dengan hasil rerata dari pre-test. Kenaikan pengetahuan dari peserta secara rerata sekitar $15,92 \%$.

\section{KESIMPULAN DAN SARAN}

Kegiatan pengabdian kepada masyarakat ini diwujudkan dalam bentuk pelatihan virtual yang dikemas dalam kegiatan pengabdian kepada masyarakat internasional (International Community Services) atau disingkat ICOSE 2020. Kegiatan yang mengusung tema "IT for better education" ini turut mensukseskan gerakan Sustainable Development Goals (SDG) oleh United Nations, terutama program Quality Education yang bertujuan untuk "ensure inclusive and equitable quality education and promote lifelong learning opportunities for all".

Hasil evaluasi pelaksanaan kegiatan dilaksanakan dengan sangat baik. Hal ini terlihat dari rerata tingkat kepuasan peserta di atas 3,5 (skala 1-4). Sedangkan tingkat serapan materi bagi peserta juga sangat baik, karena terjadi peningkatan pengetahuan peserta sekitar $15,92 \%$ dari sebelumnya. Dengan melihat antusiasme masyarakat terhadap kegiatan semacam ini, perlu dilakukan kegiatan pengabdian masyarakat internasional (International Community Services) secara rutin, misalnya tiap tahun atau tiap 2 tahun.

\section{UCAPAN TERIMA KASIH}

Penulis mengucapkan banyak terima kasih kepada semua pihak yang telah mensukseskan kegiatan ini. Mitra yang digandeng untuk kegiatan ini adalah SMP dan SMA Umar Mas'ud, dari Kecamatan Sangkapura, Bawean, Gresik. Penulis mengucapkan terima kasih kepada dosen-dosen di FISE, MSU, Malaysia yang telah berkolaborasi dalam penyampaian materi sebagai instruktur pada pelatihan ini. Penulis menyatakan tidak ada konflik kepentingan dengan pihak-pihak yang terkait dalam kegiatan pengabdian kepada masyarakat ini.

\section{DAFTAR PUSTAKA}

Arisandi, D., Rachmawati, D., \& Aulia, I. 2018. Pengembangan Computer-Based Test sebagai Strategi Peningkatan Efisiensi Evaluasi Kegiatan Belajar Mengajar. Jurnal Insitusi Politeknik Ganesha Medan Vol. 1(1). Pp. 1-8.
Cao, S., \& Liu, H. 2019. Effectiveness Analysis of Edmodo-Based Blended English Learning Mode. International Journal of Emerging Technologies in Learning (IJET) Vol. 14(18). Pp. 64-75.

Costa, C., Alvelos, H., \& Teixeira, L. 2012. The use of Moodle e-learning platform: a study in a Portuguese University. Procedia Technology vol. 5. Pp. 334-343.

Dellos, R. 2015. Kahoot! A digital game resource for learning. International Journal of Instructional Technology and Distance Learning Vol. 12(4). Pp. 49-52.

Fauzi, A. 2017. The effect of Edmodo on students' writing skill in recount text. International Journal of Pedagogy and Teacher Education Vol. 1(2). Pp. 73-79.

Haryoko, S. 2009. Efektivitas Pemanfaatan Media Audio-Visual sebagai Alternatif Optimalisasi Model Pembelajaran. Jurnal Edukasi Elektro Vol. 5(1). Pp. 1-10.

Heriadi, A., \& Satyareni, D. H. 2013. Rancang Bangun Ujian Online dengan Optimasi Pemilihan Soal. Seminar Nasional Teknologi Informasi dan Multimedia Vol. 1(1). Pp. 19-24.

Oproiu, G. C. 2015. A study about using e-learning platform (Moodle) in university teaching process. Procedia-Social and Behavioral Sciences 180; Bucharest, Romania. Pp. 426432.

Retnoningsih, E. 2017. Perbandingan Learning Management System Edmodo dan Moodle dalam Pembelajaran Online. Information System for Educators and Professionals Vol. 1(2). Pp. 221-230.

Syamsinar, S., et al. 2020. Pengabdian Media Pembelajaran Hot Potatoes Bagi Guru di Madrasah Aliyah Ddi Ihyaul Ulum Baruga Majene. Abdimas Toddopuli: Jurnal Pengabdian Pada Masyarakat Vol. 1(2). Pp. 117-124.

Yasa, A. D. 2020. Pengembangan E-Evaluation Berbasis Aplikasi Hot Potatoes Untuk Siswa Kelas V Sekolah Dasar. Jurnal IImiah Sekolah Dasar Vol. 4(1). Pp. 26-32. 